\title{
STUDYING THE INSTRUCTIVE AND CONCERT ETUDES AS THE BASIS OF FORMING STUDENTS' TECHNICAL SKILLS IN THE PIANO CLASS
}

\author{
Alexander Sklyarov ${ }^{1}$ \\ ${ }^{1}$ Department of Piano, Kharkiv State Academy of Culture, Kharkiv, Ukraine \\ proskliarov@gmail.com \\ ORCID: http://orcid.org/0000-0003-0720-9838 \\ ARTICLE INFO \\ ABSTRACT \\ Article history: \\ Received date 24.12.2019 \\ Accepted date 16.01.2020 \\ Published date 30.01 .2020 \\ In order to solve the problem of the choice of the performing repertoire, which will \\ Section: \\ Professional Development \\ help to improve the quality of the educational preparation of the applicants, the article \\ reveals the main varieties of technical difficulties for musicians who are not pianists \\ by profession. It is outlined the circle of instructional and concert etudes that can be \\ D O I \\ useful in overcoming technical difficulties and forming an artistic vision of works in \\ $10.21303 / 2313-8416.2020 .001156$ \\ the piano class at different stages of study. It is developed systematization of the educa- \\ tional material. It is provided comments and recommendations on the appropriateness \\ of the use of the studies of any composers under study in the pedagogical practice. \\ KE Y W ORD S \\ Thus, it is identified the most suitable piano etudes for the initial stage of education \\ of the educational recipients; it is made a comparative analysis of the K. Czerny's and \\ instructional etude \\ piano technique \\ small technique \\ octave technique \\ pianistic difficulties \\ performance \\ skill \\ educational repertoire \\ M. Clementi's etudes; it is relevant composer-defined works for the transition from \\ instructional to concert etudes. \\ It is analyzed and organized by types of piano technique the instructional etudes by \\ K. Czerny, K. Leshkhorn, M. Moshkovsky, M. Clementi, J. Kramer, E. Zauer, V. Zir- \\ ing, O. Gedike, R. Valashek, and concert etudes by F. List, F. Chopin, S. Rachmaninov.

\section{Introduction}

The discrepancy between the technical capabilities of the contractor, the requirements of musical works creates a problem when choosing repertoire. Consequently, the development of technical skills of students who are studying in the piano class requires special attention. Teachers of the piano from the first lessons face with the inadequacy of technical training of many students. This is reinforced by the fact that entrants of vast majority of specializations of specialty «Musical art» are accepted to the University without passing the exam on the subject.

\section{Literature review}

Modern piano teaching requires from the teacher to practice and perfect performing technique of the future musician every day.

V. Bordonyuk [1] in his thesis considers the piano works of three composers of the XIX and XX centuries, such as F. Shopen, A. Scriabin and K. Debussy. Special attention is paid to finding the symbols, certain semantic indicators of the musicians' etudes, gave them a detailed analysis. E. Mykhailova [2] also gives a description of M. Clementi’s etudes «Gradus ad Parnassum». As the author says: «M. Clementi's work and achievements in the field of pianist technique became a striking example of the embodiment of the "English" nature of pianism» [2]. Perhaps this contributed to the introduction and transformation of the first regular exercise in concert etudes. Ya. Shypailo in his article [3] considered the issue of coordination of hands and its importance in the execution of various works and influence on the realization of artistic intentions of the composer. However, as examples, the author addressed only tangentially to the C. Czerny's and F. List's etudes. Although the etude is the basis for practicing the necessary technical skills, D. Gultsova [4] in an article, which is devoted to the genre and the style of study, reveals the historical background of the emergence of one or another of their species. However, in the works of K. Debussy does not give specific 
examples and recommendations for their implementation and necessary to use them for achieve a certain level of technical skill.

Analysis of the literature shows that there are not any comments and recommendations about the appropriateness of the use etudes of certain composers in pedagogical practice. Thus, systematization of educational material based on the diverse technical challenges of the piano is very relevant to the practice of piano teachers.

\section{The aim and objectives of research}

The article aim to outline the main problems in the technical development of students in the piano class and identify ways of overcoming them.

To achieve this aim it is necessary to solve the following objectives:

- to identify the most suitable piano etudes for the initial stage of training of students;

- to make comparative analysis of K. Czerny's and M. Clementi's etudes;

- to determine from the piano work of composers appropriate works for the transition from instructional to concert etudes.

\section{Features of studying of instructive and concert etudes with students in the piano class}

The discrepancy between the artist's technical skills and the requirements for the works creates a problem to choose a repertoire. Thus, the development of the technical skills of piano students requires special attention. Piano teachers have come across the problem of the technical inadequacy of many students from their first lessons.

For students who are in the initial stages of piano development, teachers should provide G. Beren's light sketches in the repertoire (they are offered in more detail in a separate edition of «32 Selected Etudes» (Op. 61 and 88). K. Leshkhorn’s (Op. 66), K. Czerny - G. Germer's etudes are not difficult and useful.

A large selection of exercises is contained in the famous collections of M. Moshkovsky, K. Czerny (Op. 261, 299, 636, 718, 821, 849). They are based on etudes created for the development of finger technology. The author pays considerable attention to the scales, arpeggios. Students are unlikely to know K. Czerny as the author of a significant pedagogical work «A Complete Theoretical and Practical Piano School Proven in Progressive Sequence from Primary Education to Higher Completion». In this work K. Czerny first drew attention to the need for artistic execution of scales - different strokes (legato, staccato), metric accents, nuances (crescendo, diminuendo).

While working on the K. Czerny's and M. Clementi's etudes, it is necessary to focus students' attention on different approaches of authors to the role of fingers, hands, whole arm. It is important to remember that $\mathrm{K}$. Czerny had a progressive view of technique as a means of embodying artistic images, did not separate the activity of the fingers from the hand. M. Clementi advised to use the weight of the hand to obtain a rich and deep sound. It was these provisions that formed the basis for the further development of pianism.

At the same time, M. Clementi's «Step to Parnassus» is a useful and popular collection of etudes. The three-volume set of exercises «contains 100 works in different genres - etudes, preludes, fugues, canons, sonatas for piano, varied in content and scope of performing tasks» [5]. It is worth telling students about such details of the structure of the collection in order to look with other eyes at M. Clementi's achievements and the importance of technology in the context of other components of the skill. To look closely at M. Clementi's etudes, attention will be drawn to the fact that the author attaches importance to the development of positional type finger technique.

For the development of wrist mobility should refer to the J. Kramer's etudes. Although he was a M. Clementi's student of, he still had a more progressive view of improving virtuosity. Among his sketches there are many that are aimed at the development of the technique of double notes, stretching the fingers and changing the position of the hand.

It is appropriate to list some octave etudes by grouping them into a separate group. They will help students to master a very difficult kind of technique. First of all, these are K. Czerny's works (Op. 740, No. 33 and No. 38). In our opinion, item No. 33 offers students more problems due to the jumps not only of octaves in the right-hand party, but also of the left-wing party. It is requires clear 
coordination of movements, careful attention to fingering, strokes. It would be advisable for the student to study the left hand separately first, to avoid paying attention to it when using both hands.

The octave etude of E. Zauer E-dur is also useful. Throughout the work, the composer keeps the staccato stroke unchanged for octaves. This is definitely a great task for the student. However, due to the good use of the hands - the octaves alternate in the left and right, as well as the martellato - the performer is able to keep up. However, in contrast to K. Czerny's etudes, the etude is larger and requires some endurance.

On the contrary, the octave etudes of V. Ziring (Op. 10, No. 2, No. 3) are attractive with their conciseness, in particular the first one, since it aims at the development of the brush when performing octave rehearsals. Etude No. 3, in addition to the linear movement of the octaves in the left and right hands, also has thematic material laid out in octaves and chords. Easy execution with a clear upper voice, free tempo with accelerando and ritardando, a brilliant concluding passage with parallel octaves bring the sketches closer to the concerts and can be a touchstone to high artistic models in this genre.

It is also possible to consider octave etudes by O. Gedike (Op. 95, No. 3 and No. 5). The first of these is very complex, but requires some stamina when performing reactive rehearsals. In the second etude (No. 5) A. Gedike also uses chord technique, double notes (tertiary, sext). This work is expressive, bright and useful.

An octave etude by R. Valashek (Op. 2) is not so often used in the educational repertoire. It is very complex, with many black keys, technical and artistic tasks. The student should be persistent in mastering octave sequences, jumps, rehearsals, chord episodes and complex passages of small technique. Some chords have a wide range of nona and decimals. It may be advisable to use this etude occasionally at a variety show. If the student overcomes all difficulties, in the future, undoubtedly, the young performer will have no problems in interpreting complex virtuoso works.

The transitional stage from the instructional to the concert etudes may be «The Twelve Etudes» by F. List in the first edition. They were created by the composer in 1826 and are now known as youth. However, F. List worked on them for a long time (in 1837 the second edition was published, and in 1851 - the third) [6].

Initially, F. List planned to create «Etudes for Piano in the Form of Forty-Eight Exercises in All Major and Minor Tones ...», but only twelve were written in flat tones. The second edition $-\ll 24$ Great Etudes for Piano» was also not completed, and only twelve were published. This edition and the latest - «Etudes of Higher Performing Skills» - are unlikely to be used in pedagogical practice with students who are not pianists by profession [7]. So, etudes can be the starting material for sophisticated virtuoso plays.

Many composers have worked productively in the genre of concert piano etude. Some students of variety and choral specializations want to perform, first of all, F. Chopin's etudes. It is often perform those that seem simple: No. 2 and No. 9 (from Op. 25) or slow - No. 3, No. 6 (Op. 10), No. 7 (Op. 25).

Thus, referring to F. Chopin's etudes, it is important that the student becomes acquainted with J. Milstein's work «Chopin's advice to pianists» [8]. It will help to understand that the art of singing the piano is closely linked to the flexibility and freedom of hands. It is interesting for conductors to learn about pianistic breathing, the connection of pianistic ways to vocal art. The author of the book very carefully and accessibly covers the peculiarities of the technical system of the brilliant Polish composer. It is hardly advisable to study F. Chopin's etudes without such theoretical training.

The enormous role which played the transformation of the etude genre by F. List and F. Chopin contributed to the fact that concert etudes occupy a special place in the piano literature.

Talented students strive to play not only a complex repertoire, but one that they would enjoy. However, «it must be remembered that true, truly artistic performance can only be expected when the musical and technical means of performance meet the musical and technical requirements of the work» [9].

Etudes-paintings by S. Rachmaninov wish to perform many virtuosically capable young musicians. Etudes (Op. 33) are mostly quite dramatic in the play's coloration. The slow (in the first part) c-moll study can be done by a student with a large and flexible hand. But is this enough? For a musician who has not mastered the entire piano sound palette, this is a difficult task. Wide power- 
ful chords and melody sounds that are «entangled» in the arabesque of the sixteenth, four invoices (and sometimes five) that require timbre and dynamic differentiation, and, above all, deep imagery make this etude difficult, yet extremely useful in the pedagogical repertoire. «The execution of each etude is a serious artistic and technical task. Inspiration and simplicity, conciseness and diversity in the choice of expressive means - these are the qualities that are, above all, necessary for performers who turn to the etudes-paintings of S. V. Rachmaninov» [10].

It is also possible to refer to some O. Scriabin's etudes. His etudes are an important artistic contribution to piano literature, a school of the highest pianistic mastery of a new type: a school of mastering the so-called «technique of nerves» and mastery of the execution of various technical formulas, which require exceptional dexterity, flexibility of movements; a school of playing subtle sounds and complex rhythms.

The first series of etudes (Op. 8) consists of twelve plays - pathetically dramatic, light in imagery, sublime. Which student is not attracted to the dis-moll etude - rebellious and impetuous, strong-willed and ardent? Pianists know that the technical aspect of this work is not too complicated. With sufficient stretching of the fingers and a free left hand, it is easy to find the point of support (third finger) for free movements of the hand and forearm. This etude is very useful, first of all, for artistic, emotional development.

The beginning of the twentieth century is pointed out new ways of development of piano art. Using the example of K. Debussy's etudes, students will be able to see the strong connection of musical eras. Dedicated to F. Chopin, etudes of the French composer also pay tribute to K. Czerny. The first of these, a 5-fingers etude by K. Czerny, will show the student the wealth of opportunity contained in a simple five-finger formula. This work is full of contrasts: harmonious, emotional, psychological.

K. Debussy's «Twelve Etudes» have an extraordinary pianistic and artistic value. Written at the end of life, they are the result of the composer's creative search in the field of melody, harmony, rhythm. Is it possible to keep a capable student - choir master or conductor - away from this treasure trove of world music art?

The best way to get acquainted with S. Prokofiev's style is to study the «Four Etudes» (Op. 2). S. Prokofiev emphasized that the new in his work is connected with these four etudes, which opened in it a subtle direction. The young author pursued certain technical goals, creating this opus. Etudes No. 1 and No. 3 are useful for the development of great technology, No. 2 helps students in their quest to achieve finger equality and speed, No. 4 teaches the accuracy of hitting when jumping.

Undoubtedly, S. Prokofiev's etudes are technically complex. But are there any easy concert pieces? There are only those that are available to a student. These etudes are studied for the purpose of developing virtuoso students' features and their artistic imagination.

\section{Research results}

Formation of students' technical skills of the piano class based on scales, technical exercises and instructional etudes is the limitless topic. However, it is localized every time an educator deals with an individual student. Individual problems require individual approaches and remedies. It is impossible to assume that the teacher will not understand what it is necessary for each individual student at different stages of technical development: to take care of the speed of the fingers of the right hand or to pay attention to stiffness of the left hand, etc. Our task is only to help the teacher to find out which path will be the shortest and most rational, to focus its attention on the relevant methodological literature and appropriate technical exercises. And most importantly, it is necessary always remember the main purpose of technical preparation - to serve the physical, emotional relaxation of the student to embody its own artistic intentions when performing a musical work.

\section{Conclusions}

Consistent solution of the tasks of the article allows to reach the following conclusions:

1. Etudes of G. Berens, K. Leshkhorn, K. Czerny - G. Germer are the most suitable for the initial stage of studying the piano. In the case of problems with small equipment, it is useful to practice gamma and arpeggio using the etudes of M. Moshkovsky or K. Czerny (Op. 261, 299, 636, $718,821,849)$. 
2. While working on the K. Czerny's and M. Clementi's etudes, the teacher should make students pay attention to the different approaches of the two composers to the roles of fingers, shoulder apparatus and hands. It is important to remember that K. Czerny was progressive and used technique as a way of transmitting artistic images, did not separate the functions of the fingers from the functions of the hand (as M. Clementi did), and advised to use the weight of his hands to achieve a thick and deep sound.

3. The transition from instructional (instructive) to concert etudes can be accomplished through the first edition of «Twelve Etudes» by F. List.

\section{References}

[1] Bordoniuk, V. I. (2008). Stylistyka symvolizmu v modyfikatsii fortepiannykh zhanriv preliudii ta etiudu v XIX - pochatku XX stolit. Odesa, 14.

[2] Mykhailova, E. Yu. (2018). Europeanian piano school of the earyl nineteenth century: the establishment of pianistic traditions (up to the 200th edition of the «Gradus ad Parnassum» Mucio Clementi). Chasopys Natsionalnoi muzychnoi akademii Ukrainy imeni P. I. Chaikovskoho, 3 (40), 66-77.

[3] Shypailo, Ya. (2011). Deiaki aspekty formuvannia pianistychnykh navychok muzykanta-pochatkivtsia na shliakhu do opanuvannia fortepiannym mystetstvom. Molod i rynok, 10 (81), 145-152.

[4] Hultsova, D. P. (2016). Poetyka etiuda v konteksti zhanrovo-stylovoi spetsyfiky tvorchosti K. Sen-Sansa ta K. Debiussi. Mizhnarodnyi visnyk: kulturolohiia, filolohiia, muzykoznavstvo, II (7), 184-190.

[5] Stepanova, O. Yu. (2018). Pianizm londonskoi ta videnskoi fortepiannykh shkil: komparatyvnyi analiz. Sumy, 224.

[6] Gulcova D. P. (2016) «Transcendental Etudes» by Franz Liszt and Sergei Lyapunov in line with the philosophy and genre-style romanticism searches. Muzichne mistectvo i kultura, 23, 104-116.

[7] Buase, A. (1964). Uroki Lista. Leningrad: Muzyka, 66.

[8] Milshtein, Ia. I. (1967). Sovety Shopena pianistam. Moscow: Muzyka, 119.

[9] Khentova, S. M. (1966). Vydaiuschiesia pianisty-pedagogi o fortepiannom iskusstve. Moscow, Leningrad: Muzyka, 315.

[10] Muliar, P. M. (2009). Styl tvoru i vykonavskoi interpretatsii v aspekti vzaiemodii klasychnoho ta aklasychnoho u fortepiannomu mystetstvi. Odessa, 17. 